\title{
Araucaria angustifolia (bert.) Otto kuntze): Comparative evaluation of phenolic composition, antioxidant and antimicrobial activities of seeds cooking water
}

\author{
Araucaria angustifólia (bert.) Otto kuntze): Avaliação comparativa da composição dle fenólicos, \\ atividade antioxidante e antimicrobiana das águas de cozimento das sementes
}

Araucaria angustifólia (bert.) Otto kuntze): Avaluación comparativa de composición fenólica, actividad antioxidante y antimicrobiana de aguas de cocción de semillas

Received: 07/06/2021 | Reviewed: 07/09/2021 | Accept: 07/09/2021 | Published: 07/21/2021

Iria Pedroso da Cunha

ORCID: https://orcid.org/0000-0001-8664-6264 Universidade Federal de Santa Catarina, Brazil E-mail: iria.pedroso@ufsc.br Ericson Kubrusly Gonçalves ORCID: https://orcid.org/0000-0003-0947-2998 Universidade Federal de Santa Catarina, Brazil E-mail: ericson.kubrusly@ufsc.br

Luís Eduardo Silva Nascimento ORCID: https://orcid.org/0000-0002-5862-6482 Universidade Federal de Santa Catarina, Brazil E-mail: luiseduardo_sn@hotmail.com

Denise Wibelinger de Melo ORCID: https://orcid.org/0000-0001-5334-0728 Universidade Federal de Santa Catarina, Brazil E-mail: deni.wibelinger@gmail.com

Fabíola Carina Biluca ORCID: https://orcid.org/0000-0003-0511-9628 Universidade Federal de Santa Catarina, Brazil E-mail: fabiolabiluca@gmail.com Luciano Vitali ORCID: https://orcid.org/0000-0002-1664-6346 Universidade Federal de Santa Catarina, Brazil E-mail: luciano.vitali@ufsc.br

Ana Carolina de Oliveira Costa ORCID: https://orcid.org/0000-0002-5101-9604 Universidade Federal de Santa Catarina, Brazil E-mail: ana.costa@ufsc.br

Deise Helena Baggio Ribeiro ORCID: https://orcid.org/ 0000-0001-6023-9812 Universidade Federal de Santa Catarina, Brazil

E-mail: deise.baggio@ufsc.br

Edna Regina Amante

ORCID: https://orcid.org/0000-0001-9593-5674 Universidade Federal de Santa Catarina, Brazil E-mail: e.amante@ufsc.br

\begin{abstract}
Araucaria angustifolia var. angustifolia and Araucaria angustifolia var. indehiscens, seeds (common pinhão and monkey pinhão) are consumed after cooking, coats and water represent waste. In this work, pinhão was submitted to different cooking conditions, the water extracts were analyzed to determine and identify their phenolic compounds content, antioxidant activity and antimicrobial potential. Cooking for 45 minutes without addition of sodium chloride resulted in residual water with highest content of phenolic compounds and antioxidant activity (DPPH and FRAP), both for the common pinhão and for the monkey pinhão. Protocatecuic acid, vanillin and coniferaldehyde were identified and quantified by HPLC-ESI-MS/MS as the most prevalent phenolic compounds. No antimicrobial potential was observed against Salmonella enterica Typhimurium (ATCC 14028), Escherichia coli (ATCC 25922), Staphylococcus aureus (ATCC 25923) and Bacillus cereus (ATCC 11778).
\end{abstract}

Keywords: Physicochemical composition; Fluorescence microscopy; Antimicrobial activity; Residue. 


\section{Resumo}

Sementes de Araucaria angustifolia var. angustifolia e Araucaria angustifolia var. indehiscens, (pinhão comum e pinhão de macaco) são consumidas após o cozimento, cascas e água representam resíduos. Neste trabalho, o pinhão foi submetido a diferentes condições de cozimento, os extratos aquosos foram analisados para determinar e identificar seu teor de compostos fenólicos, atividade antioxidante e potencial antimicrobiano. O cozimento por 45 minutos sem adição de cloreto de sódio resultou em água residual com maior teor de compostos fenólicos e atividade antioxidante (DPPH e FRAP), tanto para o pinhão comum quanto para o pinhão macaco. Ácido protocatecuico, vanilina e coniferaldeído foram identificados e quantificados por HPLC-ESI-MS / MS como os compostos fenólicos prevalentes. Nenhum potencial antimicrobiano foi observado contra Salmonella enterica Typhimurium (ATCC 14028), Escherichia coli (ATCC 25922), Staphylococcus aureus (ATCC 25923) e Bacillus cereus (ATCC 11778).

Palavras-chave: Composição físico-química; Microscopia de fluorescência; Atividade antimicrobiana; Resíduos.

\section{Resumen}

Semillas de Araucaria angustifolia var. angustifolia y Araucaria angustifolia var. indehiscens, (piñones comunes y piñones de mono) se consumen después de la cocción, la corteza y el agua representan residuos. En este trabajo, los piñones fueron sometidos a diferentes condiciones de cocción, los extractos acuosos fueron analizados para determinar e identificar su contenido de compuestos fenólicos, actividad antioxidante y potencial antimicrobiano. La cocción durante 45 minutos sin la adición de cloruro de sodio resultó en agua residual con mayor contenido de compuestos fenólicos y actividad antioxidante (DPPH y FRAP), tanto para el común como para el mono. El ácido protocatecuico, la vainillina y el coniferaldehído fueron identificados y cuantificados por HPLC-ESI-MS / MS como los compuestos fenólicos predominantes. No se observó potencial antimicrobiano contra Salmonella enterica Typhimurium (ATCC 14028), Escherichia coli (ATCC 25922), Staphylococcus aureus (ATCC 25923) y Bacillus cereus (ATCC 11778).

Palabras clave: Composición fisicoquímica; Microscopio fluorescente; Actividad antimicrobiana; Desperdicio.

\section{Introduction}

Araucaria angustifolia is a tree widely found in southern and southeastern Brazil, occurring in different varieties, among them, Araucaria angustifolia var. angustifolia and Araucaria angustifolia var. indehiscens, popularly known as "common" pinhão and "monkey" pinhão, respectively (Lima et al., 2007). These seeds are used for consumption, after cooking in water, which is usually considered as waste as well as the coats.

It is described that the residual water from the cooking presents a reddish tint, a bitter taste, due to the migration that occurs mainly from the seed coats to water (Koehnlein et al., 2012) and is a source of bioaccessible phenolics (Cunha et al., 2018).

Considering these residues, most of the published works value the seed (Macedo et al., 2020; Pereira et al., 2020; Thys et al., 2013) and not the husks or the water from the cooking of the pinhão. By identifying functional perspectives in cooking waters, new opportunities arise. Mainly, to establish applications to cooking water, adding commercial value, in addition, to provide socioeconomic advances, generating less waste or environmental problem due to its disposal, and also to justify the preservation of pine trees. However, to date, the cooking waters have not been studied for the purpose of justifying their application.

This work aimed to investigate the phenolic composition, antioxidant and antimicrobial activities of the seed cooking waters of the Araucaria angustifolia var. angustifolia and Araucaria angustifolia var. indehiscens.

\section{Methodology}

\subsection{Samples}

The seeds were collected in the city of São José do Cerrito - SC, Brazil (latitude: $27^{\circ} 39^{\prime} 45^{\prime \prime}$ South, longitude: 50 34' 48" West) where common pinhão was collected between June and July / 2018 and the monkey pinhão in the month of August / 2018. To obtain seed aqueous extract (residual waters), $100 \mathrm{~g}$ seeds were cooked in $1000 \mathrm{~mL}$ of distilled water (15, 30 and 
45 minutes - under maximum pressure) with and without salt ( $\mathrm{NaCl}$ - Tradicional Cisne brand) $\left(15 \mathrm{~g} \mathrm{~L}^{-1}\right)$. The procedure was done in a pressure cooker (Clock ${ }^{\circledR}$, São Bernando do Campo, Brazil), in triplicate.

\section{$2.2 \mathrm{pH}$, total soluble solids, minerals, soluble proteins and colorimetry}

The physicochemical analyzes were performed as proposed by AOAC (2005). Total soluble solids content was determined in an Abbe refractometer, calibrated with distilled water; minerals content in a muffle at $550{ }^{\circ} \mathrm{C}$, with prior incineration, and soluble proteins by the method of Bradford (1976). Potentiometer was used to determine $\mathrm{pH}$.

CIELab parameters $\left(L^{*}, a^{*}\right.$ and $\left.b^{*}\right)$ were determined using a colorimeter (Minolta Chroma Meter CR-400, Osaka, Japan), adjusted to operate with D65 illuminant and previously calibrated $2^{\circ}$ viewing angle.

\subsection{Determination phenolic compounds}

The total phenolic content (TPC) was determined as proposed by Singleton and Rossi (1965) with modifications made by Arriola et al. (2014), evaluated at $765 \mathrm{~nm}$ in a UV-Vis spectrophotometer (Hitachi, U-1800, Tokyo, Japan). The calibration curve used gallic acid and the total phenolic compounds content was expressed as $\mathrm{mg}$ of gallic acid equivalent per $100 \mathrm{~mL}$ sample (mg GAE $\left.100 \mathrm{~mL}^{-1}\right)$.

Phenolic compounds were identified as described by Schulz et al. (2015) with modifications. Water extract (10 mL, pH 2) were partitioned with ethyl ether and centrifuged at $4000 \mathrm{rpm}$ (Hermle, Z 200A, Wehingen, Germany) for 10 minutes, three times. The supernatants were combined and vacuum concentrated at $40{ }^{\circ} \mathrm{C}$ until complete drying. They were resuspended in 1 $\mathrm{mL}$ of methanol and diluted 10 times for LC-ESI-MS/MS, (model 1200 Series, Agilent Technologies, Germany) analysis.

The conditions were: Synergi ${ }^{\mathrm{TM}}$ column $(4.0 \mu \mathrm{m}, 2.0$ x $150 \mathrm{~mm}$ d.i., Phenomenex, USA). The mobile phase consisted of a solution of $95 \%$ methanol and $5 \%$ water (A) and water with $0.1 \%$ formic acid (B). The separation was performed at $30{ }^{\circ} \mathrm{C}$ using gradient elution according to the following steps: 0-5 min, $10 \% \mathrm{~A} ; 5-7 \mathrm{~min}, 90 \% \mathrm{~A} ; 7-10 \mathrm{~min}, 90 \% \mathrm{~A} ; 10-17 \mathrm{~min}, 10$ $\% \mathrm{~A}$. The flow rate was $250 \mu \mathrm{L}$. min- $^{-1}$ and the injection volume was $10 \mu \mathrm{L}$.

The HPLC system was coupled to a MS - triploquadrupole and linear trap ion analyzer (model Q Trap 3200, Biosystems / MDS Sciex, Canada). The ionization source was electrospray (TurbolonSpray, Applied Biosystems / MDS Sciex, Concord-ON, Canada) in negative mode. The used conditions were: capillary needle maintained at $-4500 \mathrm{~V}$; curtain gas at 10 psi; temperature of $400{ }^{\circ} \mathrm{C}$; gas 1 and 2 at $45 \mathrm{psi}$, and collision gas, medium. Analyst software version 1.5.1 was used to acquire and process the obtained data.

The standards ( $\mathrm{n}=43$, Sigma- Aldrich, St. Louis, USA) were prepared with a stock solution $\left(1000 \mathrm{mgL}^{-1}\right.$ in $100 \%$ HPLC grade methanol) and used to prepare the calibration curve by appropriate dilution of the mixture. Folin-Ciocalteu reagent, gallic acid and ultrapure phenolic standards were obtained from All solvents for chromatography analysis were of chromatographic grade.

\subsection{In vitro antioxidant activity}

The antioxidant activity by the DPPH method was determined as proposed by Brand-Williams et al. (1995) with modifications by Arriola et al. (2014). The absorbance of the resulting solution was evaluated at $515 \mathrm{~nm}$ in a UV-Vis spectrophotometer (Hitachi, U-1800, Tokyo, Japan). The calibration curve was constructed using solutions containing known concentrations of Trolox. The results were expressed in $\mu$ Mtrolox $100 \mathrm{~mL}^{-1}$.

The ferric reducing antioxidant power (FRAP) was determined as proposed by Benzie and Strain (1996) with smaller modifications by Arriola et al. (2014). The absorbance was measured at $593 \mathrm{~nm}$ (Hitachi, U-1800, Tokyo, Japan). The calibration curve was constructed using solutions containing known concentrations of Trolox. The results were expressed in 
$\mu$ molL ${ }^{-1}$ trolox $100 \mathrm{~mL}^{1}$. DPPH (2,2-diphenyl-1-picrylhydrazyl), TPTZ (2,2'-2,4,6-tripyridyltriazine), Trolox, were obtained from Sigma- Aldrich (St. Louis, USA).

\subsection{Antimicrobial potential}

To determine antimicrobial potential, the cooking waters were concentrated in a bench freeze dryer (Terroni ${ }^{\circledR}$ LS3000D, São Carlos, Brazil) the concentration of $2.7 \mathrm{~g} \mathrm{~mL}^{-1}$ and $4.0 \mathrm{~g} \mathrm{~mL}^{-1}$ of monkey (MPE) and common pinhão (CPE), respectively. The tested strains were: Salmonella enterica Typhimurium (ATCC 14028), Escherichia coli (ATCC 25922), Staphylococcus aureus (ATCC 25923) and Bacillus cereus (ATCC 11778).

The antimicrobial potential was determined, in triplicate, by the agar diffusion method, by paper disc and in wells as recommended by the National Committee for Clinical Laboratory Standards in the M2-A8 standard.

Mueller Hinton agar (MH) was seeds, by surface spread, the disks were impregnated with CPE $\left(4.0 \mathrm{~g} \mathrm{~mL}^{-1}\right.$ and $2.0 \mathrm{~g}$ $\left.\mathrm{mL}^{-1}\right)$, MPE (2.7 $\mathrm{g} \mathrm{mL}^{-1}$ and $\left.1.4 \mathrm{~g} \mathrm{~mL}^{-1}\right)$ and sterile distilled water, $0.05 \%$ ciprofloxacin, as controls. MH agar was also inoculated, by pour plate technique, and wells of approximately $6 \mathrm{~mm}$ in diameter, the wells were filled with $30 \mu \mathrm{L}$ of the same tested solutions. The dishes were incubated for 24 hours at $35^{\circ} \mathrm{C}$.

\subsection{Fluorescence microscopy}

The pinhão water that presented the highest TPC was analyzed by transferring an aliquot to glass slides and viewed under fluorescence microscope (OLYMPUS ${ }^{\circledR}$ BX4, Tokyo, Japan) employing auto fluorescence to identify the presence of structural phenolic compounds.

\subsection{Statistical analysis}

Statistical analysis of the data was performed using STATISTICA 13.3 (TIBCO Software Inc., Palo Alto, CA). The results were submitted to one-way analysis of variance (ANOVA), followed by Tukey's test ( $\mathrm{p}$ 0.05). All quantitative analyzes were performed in triplicate and the results were expressed as mean \pm standard deviation (SD).

\section{Results and Discussion}

The presence of sodium chloride in the cooking of both varieties of pinhão completely changes the profile of the cooking waters. It can be explained by the salt extractive effect on the compounds of interest, in addition to the lixiviation or even the attachment of other compounds to the coats.

Common pinhão water shows a higher $\mathrm{pH}$ than monkey pinhão in the presence of salt. The total soluble solids as predicted increase with the addition of the cooking salt (Table 1).

The both varieties also presented different behavior regarding salt fixation, since there was less loss of it as total soluble solids. The same behavior was expected for the minerals, but both presented similar ash content in the different cooking times with and without salt.

The soluble protein fixation occurs, probably in almonds, when the pinhão is cooked with salt, compared to both samples without salt. Even so, it was observed a significant release of soluble protein, at different cooking times with and without salt, for the common pinhão. However, was not recorded soluble proteins in the cooking waters of monkey pinhão with salt at 30 and 45 minutes of cooking.

Soluble proteins contribute to the total soluble solids fraction, as well as draws attention to possible expected differences in the bioaccessibility of the phenolic compounds. In subsequent studies, the tanning effect of the pinhão phenolic 
compounds on the presence and absence of salt and the consequences of this fact on the functional properties of these aqueous extracts with and without salt at different cooking times for the two pinhão varieties should be investigated.

Table 1. Titratable acidity, $\mathrm{pH}$, total soluble solids, minerals, and soluble proteins in the cooking waters of the common and monkey pinhão, in different cooking times with and without salt.

\begin{tabular}{|c|c|c|c|c|}
\hline Sample & pH & TTA (\%) & TSS $\left({ }^{\circ}\right.$ BRIX) & $\begin{array}{c}\text { Minerals } \\
\text { g } 100 \mathrm{~mL}^{-1}\end{array}$ \\
\hline
\end{tabular}

\begin{tabular}{llllll}
\hline $\mathrm{C} 1$ & $5.61 \pm 0.07^{\mathrm{aA}}$ & $0.18 \pm 0.03^{\mathrm{aABC}}$ & $0.01 \pm 0.00^{\mathrm{dD}}$ & $0.02 \pm 0.00^{\mathrm{fH}}$ & $7.04 \pm 1.04^{\mathrm{bBC}}$ \\
$\mathrm{C} 2$ & $5.38 \pm 0.03^{\mathrm{bAB}}$ & $0.21 \pm 0.03^{\mathrm{aAB}}$ & $0.00 \pm 0.00^{\mathrm{dD}}$ & $0.03 \pm 0.00^{\mathrm{eFG}}$ & $9.37 \pm 0.88^{\mathrm{bB}}$ \\
$\mathrm{C} 3$ & $5.28 \pm 0.02^{\mathrm{bBC}}$ & $0.21 \pm 0.03^{\mathrm{aAB}}$ & $0.05 \pm 0.01^{\mathrm{dD}}$ & $0.04 \pm 0.00^{\mathrm{dF}}$ & $22.61 \pm 2.03^{\mathrm{aA}}$ \\
$\mathrm{C} 4$ & $4.99 \pm 0.03^{\mathrm{CEFG}}$ & $0.13 \pm 0.08^{\mathrm{aABC}}$ & $1.25 \pm 0.06^{\mathrm{CC}}$ & $0.08 \pm 0.00^{\mathrm{cE}}$ & $4.15 \pm 2.02^{\mathrm{cDE}}$ \\
$\mathrm{C} 5$ & $4.79 \pm 0.05^{\mathrm{dGH}}$ & $0.18 \pm 0.03^{\mathrm{aABC}}$ & $2.00 \pm 0.06^{\mathrm{bB}}$ & $0.11 \pm 0.00^{\mathrm{bC}}$ & $6.48 \pm 2.96^{\mathrm{bB}}$ \\
$\mathrm{C} 6$ & $4.66 \pm 0.10^{\mathrm{dH}}$ & $0.20 \pm 0.00^{\mathrm{aAB}}$ & $2.90 \pm 0.46^{\mathrm{aA}}$ & $0.14 \pm 0.00^{\mathrm{aA}}$ & $7.46 \pm 1.33^{\mathrm{bB}}$ \\
\hline M1 & $5.62 \pm 0.21^{\mathrm{aA}}$ & $0.13 \pm 0.03^{\mathrm{bCABC}}$ & $0.10 \pm 0.01^{\mathrm{dE}}$ & $0.01 \pm 0.00^{\mathrm{fH}}$ & $0.49 \pm 0.28^{\mathrm{cE}}$ \\
$\mathrm{M} 2$ & $5.11 \pm 0.05^{\mathrm{bcCEF}}$ & $0.16 \pm 0.06^{\mathrm{abcABC}}$ & $0.00 \pm 0.00^{\mathrm{dD}}$ & $0.03 \pm 0.00^{\mathrm{eG}}$ & $3.45 \pm 0.08^{\mathrm{bCDE}}$ \\
M3 & $4.93 \pm 0.06^{\mathrm{FFG}}$ & $0.23 \pm 0.03^{\mathrm{aA}}$ & $0.19 \pm 0.01^{\mathrm{cD}}$ & $0.04 \pm 0.00^{\mathrm{dF}}$ & $6.41 \pm 0.16^{\mathrm{aBCD}}$ \\
$\mathrm{M} 4$ & $5.22 \pm 0.03^{\mathrm{bBCE}}$ & $0.08 \pm 0,08^{\mathrm{cC}}$ & $0.30 \pm 0.01^{\mathrm{abD}}$ & $0.08 \pm 0.00^{\mathrm{cE}}$ & $0.49 \pm 0.28^{\mathrm{cE}}$ \\
M5 & $5.20 \pm 0.08^{\mathrm{bcBCE}}$ & $0.12 \pm 0.03^{\mathrm{bcBC}}$ & $0.29 \pm 0.0^{\mathrm{bD}}$ & $0.10 \pm 0.00^{\mathrm{bD}}$ & $0.00 \pm 0.00^{\mathrm{cE}}$ \\
M6 & $5.20 \pm 0.06^{\mathrm{bcBCE}}$ & $0.18 \pm 0.03^{\mathrm{abABC}}$ & $0.36 \pm 0.05^{\mathrm{aD}}$ & $0.13 \pm 0.00^{\mathrm{aB}}$ & $0.00 \pm 0.00^{\mathrm{cE}}$ \\
\hline
\end{tabular}

TTA - Titratable acidity; TSS: Total soluble solids; ${ }^{\circ}$ BRIX: Degrees Brix. C1 - Common pinhão without sal (15 minutes); C2 - Common pinhão without sal (30 minutes); C3 - Common pinhão without salt (45 minutes); C4 - Common pinhão with salt (15 minutes); C5 - Common pinhão with salt (30 minutes); C6 - Common pinhão with salt (45 minutes); M1 - Monkey pinhão without salt (15 minutes); M2 - Monkey pinhão without salt (30 minutes); M3 - Monkey pinhão without salt (45 minutes); M4 - Monkey pinhão with salt (15 minutes); M5 - Monkey pinhão with salt (30 minutes); M6 - Monkey pinhão with salt (45 minutes). Data represented by averages of each sample \pm standard deviation $(\mathrm{n}=6)$. a-f Lowercase letters different in the same column and in the same variety of pinion indicates significant difference $(\mathrm{p}<0.05)$ between applied treatments. A-H Different capital letters on the same column indicate significant difference $(\mathrm{p}<0.05)$ between applied treatments and pine cone varieties concomitantly.

Source: Authors.

The water samples exhibit distinct behavior depending on the cooking time and addition of salt to the parameters $L^{*}$, $a^{*}$ and $b^{*}$. The cooking waters tend to get redder with the addition of salt and the cooking time, which may indicate a greater carry of phenolic compounds. Both presented higher values for the parameter $b^{*}$ without the addition of salt, with 45 minutes of cooking (Table 2).

The fluorescence microscopy images of the waters of the monkey and common pinhão (Figure 1) confirm the presence of the phenolic compounds in which they are shown in agglomerates. Autofluorescence and the color variation between the red, brown and orange colors suggest the highest concentration of phenolic compounds and the bright blue color indicates the presence of lignin (structural phenolic compound).

The total phenolic content was quantified in all samples (Table 3). The effect of sodium chloride addition is clear on the release reduction of these compounds. However, the common pinhão presents significantly higher value than the monkey pinhão, at the same cooking time, without salt. 
Table 2. Evaluation of the color parameters $L^{*}, a^{*}$, and $b *$ in the cooking waters of the common and monkey pinhão in different cooking times with and without salt.

\begin{tabular}{|c|c|c|c|}
\hline \multirow{2}{*}{ Samples } & \multicolumn{3}{|c|}{ Parameters CIElab } \\
\hline & $L^{*}$ & $a^{*}$ & $b^{*}$ \\
\hline $\mathrm{C} 1$ & $50.82 \pm 0.56^{\mathrm{aAB}}$ & $2.07 \pm 0.29^{\mathrm{dDE}}$ & $14.85 \pm 0.99^{\mathrm{dEF}}$ \\
\hline $\mathrm{C} 2$ & $48.55 \pm 0.76^{\mathrm{bBCD}}$ & $3.45 \pm 0.38^{\mathrm{cCD}}$ & $18.41 \pm 0.63^{\mathrm{cD}}$ \\
\hline $\mathrm{C} 3$ & $41.01 \pm 41.01^{\mathrm{cE}}$ & $10.21 \pm 1.51^{\mathrm{acA}}$ & $25.90 \pm 40.96^{\mathrm{aA}}$ \\
\hline $\mathrm{C} 4$ & $51.95 \pm 1.03^{\mathrm{aA}}$ & $1.17 \pm 0.50^{\mathrm{dEF}}$ & $13.42 \pm 1.80^{\mathrm{dF}}$ \\
\hline C5 & $46.96 \pm 1.76^{\mathrm{bABC}}$ & $3.61 \pm 1.02^{\mathrm{cCD}}$ & $19.61 \pm 1.64^{\mathrm{bcCD}}$ \\
\hline C6 & $40.34 \pm 1.53^{\mathrm{cCD}}$ & $7.00 \pm 0.66^{\mathrm{bB}}$ & $21.05 \pm 0.62^{\mathrm{bBC}}$ \\
\hline M1 & $52.07 \pm 1.13^{\mathrm{aABCD}}$ & $1.66 \pm 0.64^{\mathrm{cdE}}$ & $14.13 \pm 1.67^{\mathrm{cEF}}$ \\
\hline M2 & $48.19 \pm 2.50^{\mathrm{aABCD}}$ & $4.41 \pm 1.55^{\mathrm{bC}}$ & $21.11 \pm 1.98^{\mathrm{abBC}}$ \\
\hline M3 & $38.50 \pm 2.57^{\mathrm{bE}}$ & $11.31 \pm 2.27^{\mathrm{aA}}$ & $23.32 \pm 2.23^{\mathrm{aB}}$ \\
\hline M4 & $52.24 \pm 6.63^{\mathrm{aABC}}$ & $-0.09 \pm 0.19^{\mathrm{dF}}$ & $10.97 \pm 0.88^{\mathrm{dG}}$ \\
\hline M5 & $51.15 \pm 0.59^{\mathrm{aD}}$ & $1.38 \pm 0.49^{\mathrm{cdEF}}$ & $15.83 \pm 0.82^{\mathrm{cE}}$ \\
\hline M6 & $48.14 \pm 2.28^{\mathrm{aE}}$ & $2.85 \pm 1.08^{\mathrm{bcCDE}}$ & $20.33 \pm 1.96^{\mathrm{bCD}}$ \\
\hline
\end{tabular}

C1 - Common pinhão without sal (15 minutes); C2 - Common pinhão without sal (30 minutes); C3 - Common pinhão without salt (45 minutes); C4 - Common pinhão with salt (15 minutes); C5 - Common pinhão with salt (30 minutes); C6 - Common pinhão with salt (45 minutes); M1 - Monkey pinhão without salt (15 minutes); M2 Monkey pinhão without salt (30 minutes); M3 - Monkey pinhão without salt (45 minutes); M4 - Monkey pinhão with salt (15 minutes); M5 - Monkey pinhão with salt (30 minutes); M6 - Monkey pinhão with salt (45 minutes). Data represented by averages of each sample \pm standard deviation $(n=6)$. a-f Lowercase letters - different in the same column and in the same variety of pinion indicates significant difference $(\mathrm{p}<0.05)$ between applied treatments. A-H Different capital letters on the same column indicate significant difference $(p<0.05)$ between applied treatments and pine cone varieties concomitantly.

Source: Authors. 
Figure 1. Fluorescence microscopy of the solids in the cooking waters of the common and monkey pinhão (45 minutes without salt).
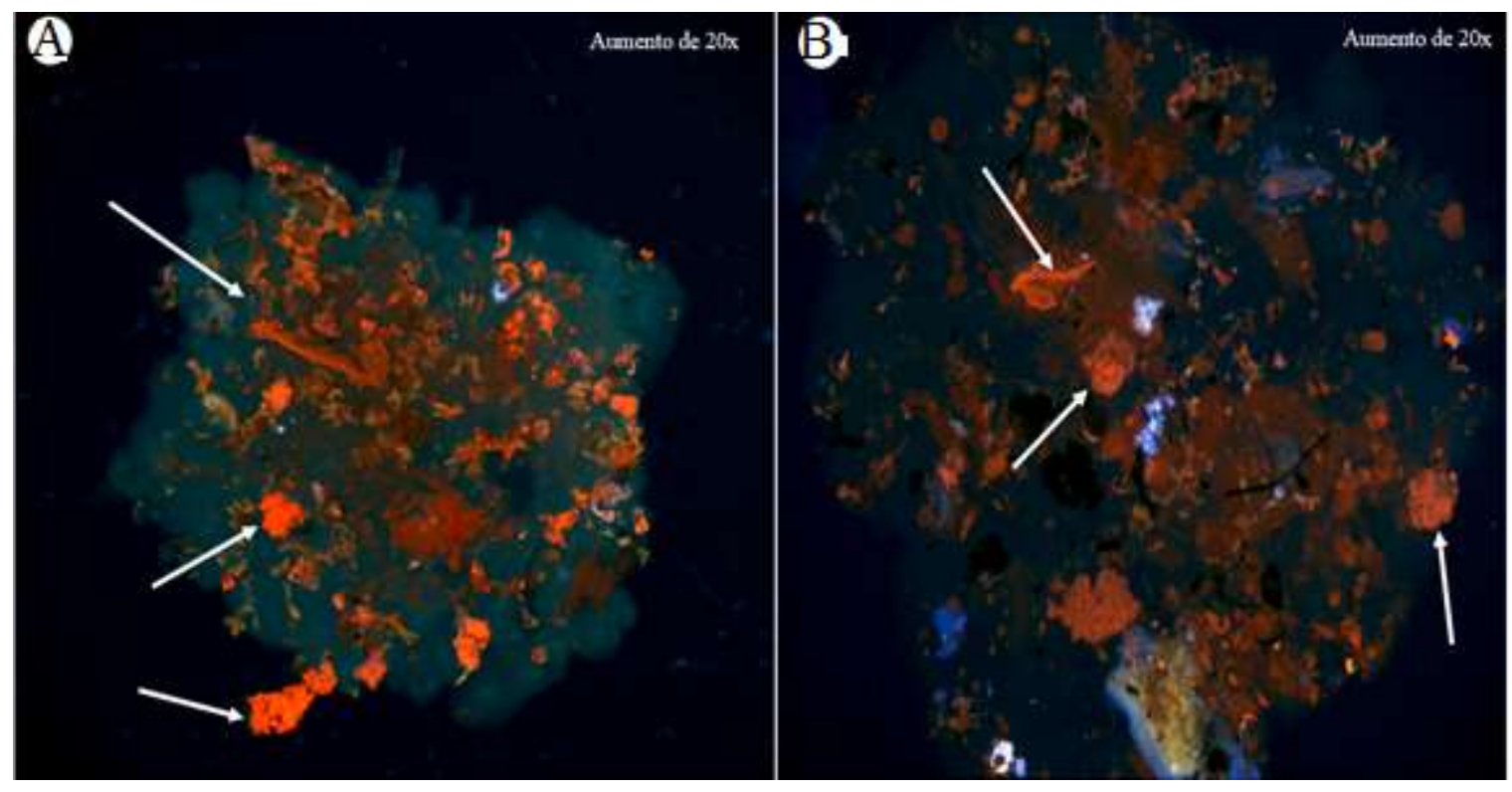

A: Microparticle of the cooking water of the monkey pinhão; B: Microparticle of cooking water of the common pinhão. Autofluorescence indicating the presence of phenolic compounds and lignin (structural phenolic compound). Red color, indicated arrows with higher concentration of phenolic compounds, and bright blue color indicates the presence of lignins.

Source: Authors.

The same results were observed to antioxidant activity evaluated by DPPH and FRAP (Table 3). After cooking during 45 minutes, without sodium chloride, the samples had the highest values for antioxidant activity, with the exception of the monkey pinhão water, by the DPPH method.

The presence of phenolic compounds in the aqueous extract of common and monkey pinhões may be important for future studies on the functional properties of these cooking waters. As well as, the functional properties of the aqueous extract of Camelia sinensis tea are attributed to phenolic compounds (Al-Obaidi et al., 2015; Shannon et al., 2018).

The protocatechuic acid (3,4-Dihydroxybenzoicacid $\left.-(\mathrm{HO})_{2} \mathrm{C}_{6} \mathrm{H}_{3} \mathrm{CO}_{2} \mathrm{H}\right)$ was the phenolic found in all cooking water samples (4.77 $\mathrm{mg} \mathrm{L}^{-1}, 3.92 \mathrm{mg} \mathrm{L}^{-1}$ from common pinhão, with and without $\mathrm{NaCl}$ and $6.49 \mathrm{mg} \mathrm{L}^{-1}, 4.05 \mathrm{mg} \mathrm{L}^{-1}$ from monkey pinhão with and without $\mathrm{NaCl}$ ), which proves aqueous extraction in absence of sodium chloride for both varieties is more efficient in extracting phenolic compounds from the seeds.

Coniferaldehyde (4-Hydroxy-3-methoxycinnamaldehyde $\left.-\mathrm{HOC}_{6} \mathrm{H}_{3}\left(\mathrm{OCH}_{3}\right) \mathrm{CH}=\mathrm{CHCHO}\right)\left(0.26 \mathrm{mg} \mathrm{L}-{ }^{1}, 0.57 \mathrm{mg} \mathrm{L}-{ }^{1}\right.$ in from common pinhão, with and without $\mathrm{NaCl}$ and $0.31 \mathrm{mg} \mathrm{L}^{-1}, 0.27 \mathrm{mg} \mathrm{L}^{-1}$ from monkey pinhão, with and without $\mathrm{NaCl}$ and) and vanillin (4-Hydroxy-3-methoxybenzaldehyde - 4-( $\left.\mathrm{HO}) \mathrm{C}_{6} \mathrm{H}_{3}-3-\left(\mathrm{OCH}_{3}\right) \mathrm{CHO}\right)\left(0.12 \mathrm{mg} \mathrm{L}^{-1}\right.$ from common pinhão, with $\mathrm{NaCl}$ and $0.17 \mathrm{mg} \mathrm{L}^{-1}$ from monkey pinhão, with $\mathrm{NaCl}$ ) were found in lower concentrations.

Among the phenolic compounds found in pinhão extracts are proanthocyanidins, derived from catechins and epicatechins, flavonol quercetin-3-glycoside, flavanone eriodictiol hexoside and two phenolic acids, these being derivatives of protocatechuic and ferulic acids (Freitas et al., 2018; Santos et al., 2018). Due to its biological properties, such as antioxidant activity, it may be potentially associated with chemopreventive (Tanaka, Tanaka, \& Tanaka, 2011), as well as other effects against chronic diseases and inflammation (D'Archivio et al., 2018). 
Table 3. Total phenolic compounds and antioxidant activity (DPPH and FRAP) of the cooking waters of the common and monkey pinhão, at different times, with and without salt.

\begin{tabular}{|c|c|c|c|}
\hline \multirow[t]{2}{*}{ Samples } & \multirow{2}{*}{$\begin{array}{c}\text { Total phenolic } \\
\text { (mg GAE } 100 \text { mL }^{-1} \text { ) }\end{array}$} & \multicolumn{2}{|c|}{$\begin{array}{l}\text { Antioxidant capacity } \\
\left(\mathrm{mM} \text { TE } 100 \mathrm{~mL}^{-1}\right)\end{array}$} \\
\hline & & DPPH & FRAP \\
\hline $\mathrm{C} 1$ & $12.13 \pm 0.22^{\mathrm{dD}}$ & $9.70 \pm 3.98^{\mathrm{cH}}$ & $68.15 \pm 1.34^{\mathrm{cD}}$ \\
\hline $\mathrm{C} 2$ & $16.93 \pm 0.80^{\mathrm{cC}}$ & $17.27 \pm 3.99^{\mathrm{bG}}$ & $95.77 \pm 2.17^{\mathrm{bB}}$ \\
\hline $\mathrm{C} 3$ & $36.37 \pm 6.71^{\mathrm{aA}}$ & $43.84 \pm 1.13^{\mathrm{aD}}$ & $209.26 \pm 2.33^{\mathrm{aA}}$ \\
\hline $\mathrm{C} 4$ & $9.28 \pm 1.78^{\mathrm{dDE}}$ & $4.70 \pm 3.15^{\mathrm{cH}}$ & $63.50 \pm 1.94^{\mathrm{cD}}$ \\
\hline $\mathrm{C} 5$ & $17.80 \pm 2.93^{\mathrm{cC}}$ & $19.13 \pm 2.48^{\mathrm{bFG}}$ & $94.64 \pm 6.57^{\mathrm{bB}}$ \\
\hline C6 & $26.99 \pm 3.36^{\mathrm{bB}}$ & $18.41 \pm 0.76^{\mathrm{bFG}}$ & $99.41 \pm 2.16^{\mathrm{bB}}$ \\
\hline M1 & $8.91 \pm 0.69^{\mathrm{cDE}}$ & $26.36 \pm 4.66^{\mathrm{dE}}$ & $50.87 \pm 1.84^{\mathrm{cE}}$ \\
\hline M2 & $17.06 \pm 1.32^{\mathrm{bC}}$ & $77.07 \pm 7.26^{\mathrm{cC}}$ & $78.20 \pm 2.99^{\mathrm{bC}}$ \\
\hline M3 & $26.53 \pm 2.87^{\mathrm{aB}}$ & $131.36 \pm 7.58^{\mathrm{bB}}$ & $100.39 \pm 3.06^{\mathrm{aB}}$ \\
\hline M4 & $6.30 \pm 1.50^{\mathrm{cE}}$ & $4.57 \pm 1.28^{\mathrm{eH}}$ & $44.18 \pm 0.74^{\mathrm{dF}}$ \\
\hline M5 & $8.19 \pm 0.23^{\mathrm{cDE}}$ & $25.64 \pm 3.89^{\mathrm{dEF}}$ & $48.50 \pm 1.25^{\mathrm{cE}}$ \\
\hline M6 & $17.83 \pm 4.15^{\mathrm{bC}}$ & $149.21 \pm 2.53^{\mathrm{aA}}$ & $74.64 \pm 3.36^{\mathrm{bC}}$ \\
\hline
\end{tabular}

GAE: Gallic acid equivalent. TE: Trolox equivalent.

$\mathrm{C} 1$ - Common pinhão without sal (15 minutes); C2 - Common pinhão without sal (30 minutes); C3 - Common pinhão without salt (45 minutes); C4 - Common pinhão with salt (15 minutes); C5 - Common pinhão with salt (30 minutes); C6 - Common pinhão with salt (45 minutes); M1 - Monkey pinhão without salt (15 minutes); M2 - Monkey pinhão without salt (30 minutes); M3 - Monkey pinhão without salt (45 minutes); M4 - Monkey pinhão with salt (15 minutes); M5 - Monkey pinhão with salt (30 minutes); M6 - Monkey pinhão with salt (45 minutes). Data represented by averages of each sample \pm standard deviation $(n=6)$. a-f Lowercase letters - different in the same column and in the same variety of pinion indicates significant difference $(\mathrm{p}<0.05)$ between applied treatments. A-H Different capital letters on the same column indicate significant difference $(\mathrm{p}<0.05)$ between applied treatments and pine cone varieties concomitantly.

Source: Authors.

The phenolic compounds extracted in the cooking waters are water soluble and differ from those found by Santos et al. (2018), who studied the hydroalcoholic extract of the common pinhão. The presence of these compounds in the cooking waters of the pinhão is not sufficient to indicate the bioaccessibility. Therefore, da Cunha et al. (2018) evaluated bioaccessibility in simulated gastrointestinal digestion in vitro and found that both pinhão extracts showed phenolic compounds bioaccessibles.

Despite of its composition and presence of phenolic compounds, the cooking waters did not show any antimicrobial potential at the concentrations tested against the selected bacteria. It is important to consider that the lack of effect can be explained by the low concentration of functional compounds on samples.

\section{Conclusion}

The present work, opens a perspective of future applications by investigating the effects of cooking time and the presence of sodium chloride on the extraction of phenolic compounds from pinhão to cooking water. The color in the brown tint tending to red reinforces the presence of these compounds, also confirmed by the fluorescence microscopy. The phenolic compounds identified by HPLC-ESI-MS/MS should be studied for its bioaccessibility, once they present antioxidant characteristics. The soluble protein retention characteristics in cooking waters, alert us to future work to identify the chemical 
mechanisms responsible for this behavior. The results of this work can indicate perspectives of use for the water from the cooking of the pinhão.

\section{Acknowledgments}

This work was supported by the Brazilian National Council for Scientific and Technological Development (CNPq, contract 304741/2014-0) and Coordenação de Aperfeiçoamento de Pessoal de Nível Superior - Brazil (CAPES, Finance Code 001).

\section{References}

AOAC International. Official Methods of Analysis. Gaithersburg. (18a ed.).

Arriola, N. A., dos Santos, G. D., Prudêncio, E. S., Vitali, L., Petrus, J. C. C., \& Amboni, R. D. M. (2014). Potential of nanofiltration for the concentration of bioactive compounds from watermelon juice. International Journal of Food Science and Technology, 49, 2052-2060. https://doi.org/10.1111/ijfs.12513.

Benzie, I. F., \& Strain, J. J. (1996). The ferric reducing ability of plasma (FRAP) as a measure of "antioxidant power": the FRAP assay. Analytical Biochemistry, 239, 70-76. https://doi.org/10.1006/abio.1996.0292.

Bradford, M.M. (1976). A rapid and sensitive method for the quantitation of microgram quantities of protein utilizing the principle of protein-dye binding. Analytical Biochemistry, 72, 248-254. https://doi.org/10.1016/0003-2697(76)90527-3.

Brand-Williams, W., Cuvelier, M. E., \& Berset, C. (1995). Use of a free radical method to evaluate antioxidant activity. Food Science and Technology, 28, 2530 .

Cunha, I. P., Melo, D. W., Verruck, S., Maran, B. M., Prudencio, E. S., \& Amante, E. R. (2018). Bioaccessibility of phenolic compounds of Araucaria angustifolia from seed water extracts during in vitro simulated gastrointestinal conditions. Food and Nutrition Sciences, 9, 1137-1146. https://doi.org/10.4236/fns.2018.910082.

Freitas, T. B. de, Santos, C. H. K., Silva, M. V. da, Shirai, M. A., Dias, M. I., Barros, L., Barreiro, M. V., Ferreira, I. C. F. R., Gonçalves, O. H., \& Leimann, F. V. (2018). Antioxidants extraction from Pinhão (Araucaria angustifolia (Bertol.) Kuntze) coats and application to zein films. Food Packaging and Shelf Life, 15, 28-34. http://dx.doi.org/10.1016/j.fpsl.2017.10.006.

D’Archivio, M., Scazzocchio, B., Silenzi, A., Giovannini, C., \& Masella, R. (2018). Role of Protocatechuic Acid in Obesity-Related Pathologies: An Update. In: Polyphenols: Mechanisms of Action in Human Health and Disease, pp.181-192. https://doi.org/ 10.1016/B978-0-12-813006-3.00014-3.

Koehnlein, E. A., Carvajal, A. E. S., Koehnlein, E. M., Coelho-Moreira, J. Das, Inácio, F. D., \& Castoldi, R. (2012). Antioxidant Activities and phenolic compounds of raw and cooked Brazilian pinho (Araucaria angustifolia) seeds. African Journal of Food Science, 6, 512-518. https://doi.org/10.5897/AJFS12.128.

Lima, E.C., Royer, B., Vaghetti, J. C. P., Brasil, J. L., Simon, N. M., \& dos Santos, A. A. (2007). Adsorption of Cu(II) on Araucaria angustifolia wastes: determination of the optimal conditions by statistic design of experiments. Journal of Hazardous Materials, 140, 211-220. https://doi.org/10.1016/j.jhazmat.2006.06.073.

Macedo, L. D., Ávila, B. P., Saraiva, J. F. R., Lacerda, M. da S., Domingues, B. P., Pereira, A. M., Guarino, E. de S. G., \& Goularte, M. A. (2020). Caracterização química e sensorial de cookies formulados com grãos crioulos e amido de pinhão (Araucaria angustifolia) starch. Research, Society and Development, 9, e3491210677. https://doi.org/10.33448/rsd-v9i12.10677.

National Comittee for Clinical Laboratory Standards. M2-A8: padronização dos testes de sensibilidade a antimicrobianos por disco-difusão: norma aprovada. (8a ed.), Anvisa, 23. Substitui a Norma M2-A7.http://www.anvisa.gov.br/servicosaude/manuais/clsi/clsi_OPASM2-A8.pdf>.

Pereira, L. P., Amante, E. R., \& Ribeiro, D. H. B. (2020). Araucaria angustifolia seeds drying behavior, flour and starch properties. Research, Society and Development, 9, e935986621. http://dx.doi.org/10.33448/rsd- v9i8. 6621.

Santos, C. H. K., Baqueta, M. R., Barros, L., Barreiro, M. F., Ferreira, I. C. F. R., Gonçalves, O. H., Bona, E., da Silva, M. V., \& Leimann, F. V. (2018). Systematic study on the extraction of antioxidants from pinhão (Araucaria angustifolia (bertol.) kuntze) coat. Food Chemistry, 261, 216-223. https://doi.org/10.1016/j.foodchem.2018.04.057.

Schulz, M., Borges, G. S. C., Gonzaga, L. V., Seraglio, S. K. T., Olivo, I. S., Azevedo, M. S., Nehring, P., Gois, J. S., Almeida, T. S., Vitali, L, Spudeit, D. A., Micke, G. A., Borges, D. L. G., \& Fett, R. (2015). Chemical composition, bioactive compounds and antioxidant capacity of juçara fruit (Euterpe edulis Martius) during ripening. Food Research International, 77, 125-131. https://doi.org/10.1016/j.foodres.2015.08.006.

Shanon, E., Jaiswal, A. K., \& Abu-Ghannam, N. (2018). Polyphenolic content and antioxidant capacity of white, green, black, and herbal teas: a kinetic study. Food Research, 2, 1 -11. https://doi.org/10.26656/fr.2017.2(1).117.

Singleton, V. L., \& Rossi, J. A. (1965). Colorimetry of total phenolics with phosphomolybdicphosphotungstic acid reagents. American Journal of Enology and Viticulture, 16, 144-158.

Tanaka, T., Tanaka, T., \& Tanaka, M. (2011). Potential cancer chemopreventive activity of protocatechuic acid. Journal of Experimental and Clinical Medicine, 3, 27-33. https://doi.org/10.1016/j.jecm.2010.12.005.

Thys, R. C. S., Aires, A. G., Marczak, L. D. F., \& Noreña, C. P. Z. (2013). The effect of acid hydrolysis on the technological functional properties of pinhão (Araucaria brasiliensis) starch. Ciência e Tecnologia de Alimentos, 33, 89-94. https://doi.org/10.1590/S0101-20612013000500014. 